\title{
Quality Implications of Some Domestic Water Supply Sources In Parts Of Umuahia, Abia State, Nigeria.
}

\author{
Ngah, S A and Abam, T.K.S. \\ Institute of Geosciences and Space Technology \\ Rivers State University of Science and Technology \\ Port Harcourt, Nigeria.
}

\begin{abstract}
Sources of domestic water supplies in parts of UmuahiaSouth Local Government Area (Old Umuahia), AbiaState, Nigeria were investigated. The area has apopulation of about 8000 people mainly farmers and civil servants living essentially in a rural setting that lacks modern facilities including modern water supply facilities. The inhabitants derive their daily water supply from streams, springs, boreholes, rain water harvesting and also from commercial water vendors using motorized or manual trucks. Incidents of outbreak of water borne diseases such as typhoid fever, dysentery and diarrhoea have been reported in the area. This sparked off curiosity on the quality of water delivered by the various sources of water supply in the area.The methods employed in the study are field investigation/sampling and laboratory analysis. A detailed field investigation and sampling exercise was carried out. Water samples were collected from two streams, one spring, four boreholes, and also from water tankers identified as the main sources of water supply to the area. Laboratory analysis was carried out at the Production Chemistry Laboratory of Shell Petroleum Development Company, Port Harcourt. The samples were analysed using standard methods. The microbial quality was estimated from the coliform counts and the concentration of heterotrophic bacteria present in the sources. The levels of concentration of the parameters were compared with World Health Organisation (WHO) and Nigerian Standards Organisation (NSO) standards for potable water supply. The results show that water in the area is acidic ( $\mathrm{pH}$ ranges from $4.9-5.15$, mean value, 5.02). Other physical and chemical parameters fall within WHO and NSO standards. However bacterial load was high in two borehole sources, the two streams and samples from commercial water vendors. The health implications of the observed quality were highlighted. The study concluded that water supply sources utilizing groundwater offer the best water quality in the area. More boreholes should be drilled for domestic water supply. Water supply from streams and springs are not potable in their untreated state and the quality of water delivered by commercial water vendors using motorized and manual water tankers and plastic cans fall far below the recommended standards for human consumption. Use of tankers (motorized or manual) to convey water to homes should be discontinued.
\end{abstract}

Keywords: water quality, domestic water supply, sources, Umuahia,

\section{Introduction}

The study area is Old Umuahia, a semi -urban district in Umuahia South Local Government Area,Abia State, Nigeria. It has a population of about 8000people mainly farmers and civil servants. Over $75 \%$ of the population live in rural settings where modern water supply facilities are lacking. As a result, the inhabitants depend on traditional and historical sources for their water supply. Such sources are generally of questionable quality, insufficient in quantity and often liable to seasonal failures. Asa result, water borne diseases like typhoid fever, dysentery, diarrhea and hepatitis remain a regular threat. The aim of this study is to assess the quality of water delivered by the various sources of water supply in use at present with a view to highlighting their potability or otherwise.The specific objectives of the study include: (a) identify the sources of water supply in Old Umuahia semi-urban area, (b) collect water samples from various sources and subject them to laboratory analysis (c) compare the results with existing water quality benchmark minimum standards and (d) assess the suitability of any source(s) for development of a sustainable water supply scheme for the study area.

\section{Description Of The Study Area}

Old Umuahia District of AbiaState,Nigeriais located within the Kwa Ibo River watershed between longitudes $5^{0} 25^{\prime}$ and $5^{0} 30^{\prime} \mathrm{N}$ and latitudes $7^{0} 28^{\prime}$ and $7^{0} 30^{\prime} \mathrm{E}$. It is drained by the Kwa Ibo River, which rises near Umuahia and flows SE with Anya River as its main tributary.The area stands on an elevation of $151 \mathrm{~m}$ above mean sea level and is made upofsix sub districts, (figure 1). 


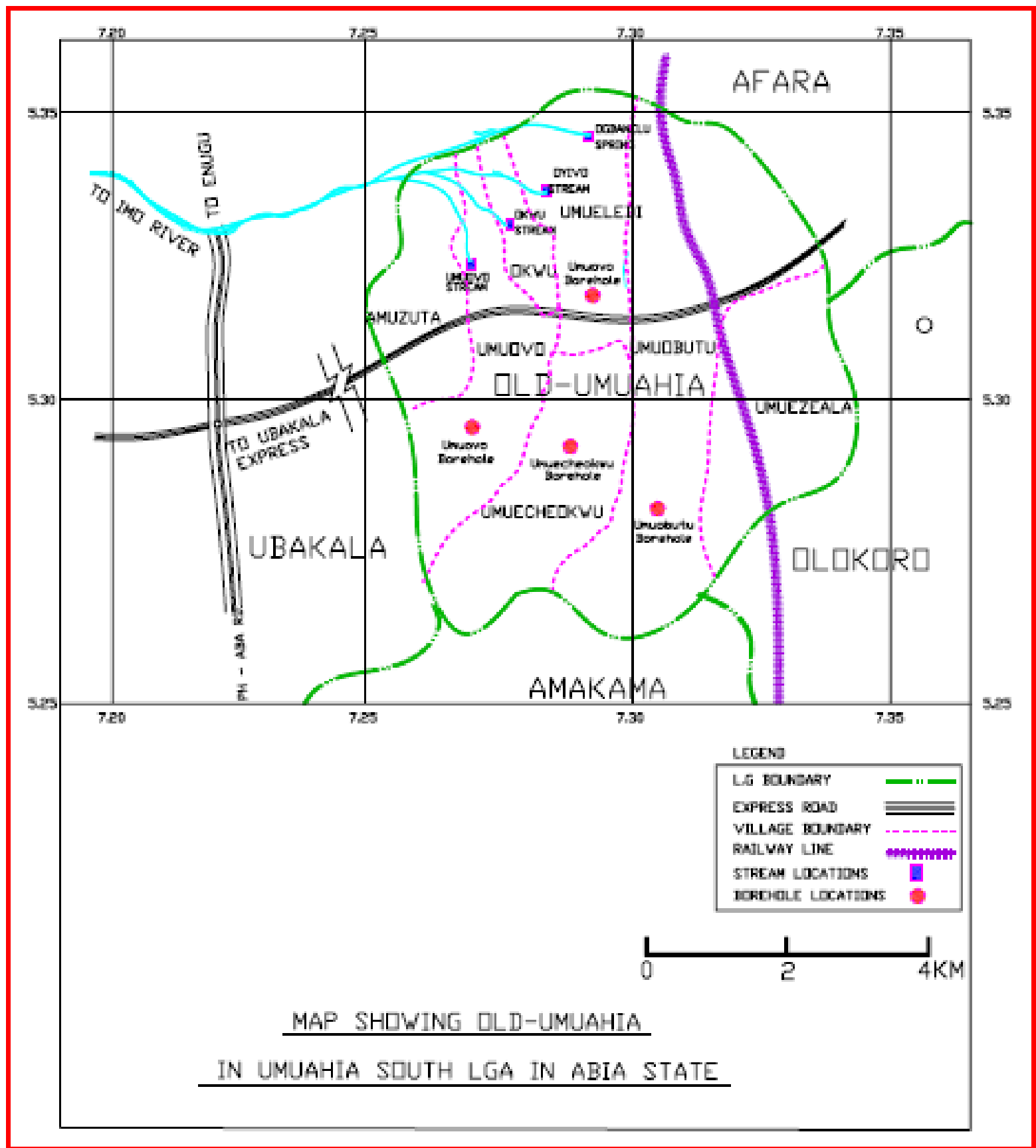

Figure 1.Study area showing sub-districts and location of existing boreholes and streams.

\section{Geology, Hydrogeology and Climate}

The oldest formation in the area is the impervious Imo shale of Palaeocene age. The Imo shale is overlain by the Bende -Ameki Formation of Eocene to Oligocene age consisting of medium to coarse - grained white sandstone, with ocassional pebbles, gray-green sandstone, blueish calcareous silt, with mottled clays and thin limestone. It also shows considerable lateral variation in lithogy. The lower part of the formation consists of fine - coarse - grained lenses of sandstones with abundant calcareous shales and thin shelly limestone. The bende-Ameki Formation is in turn overlain by the Benin Formation, Miocene to Recent in age and consisting mostly of medium- to coarse-grained, pebbly, moderately sorted sands with clay and local lenses of poorly cemented sands(Ukandu et al, 2011). Coastal Plain Sands (Benin Formation) dips southward (Igboekwe et al, 2006) and is shallow in Umudike where the expected thickness is about 200m (Ebillah-Salmon \& Partners, 1994) There are two marked seasons in the year: rainy (March-October) and dry (November- February) seasons The hottest months are January - March with mean monthly temperature of $27^{\circ} \mathrm{C}$. Relative humidity is usually high throughout the year, reaching a maximum of $90 \%$ during the rainy season. 


\section{Existing Water Supply Sources}

Historically, people of Old Umuahia area have relly on surface water sources from streams and ponds. Notable amongst the streams are the Oyivo, IyiOkwu and IyiUmuovu Streams, which are not perennial and the Ogbanelu Spring which is very difficult to access due to its difficult terrain resulting from gully erosion. Boreholes and rainwater sources have had limited successes in the past.these sources are augumented with supplies from commercial water vendors. There is no structured system of water supply.

\section{(a) Ogbanelu Spring}

The Ogbanelu Spring is a source of 'clean' water and has been a major source of drinking water for the local community for a long time. Over the years drawing water from this source has become increasingly difficult. This is because the few natural spring water sources are hard to access due to difficult terrain; since the sites are often affected by severe gully erosion. Again the quantity is inadequate to meet the domestic and industrial demands.

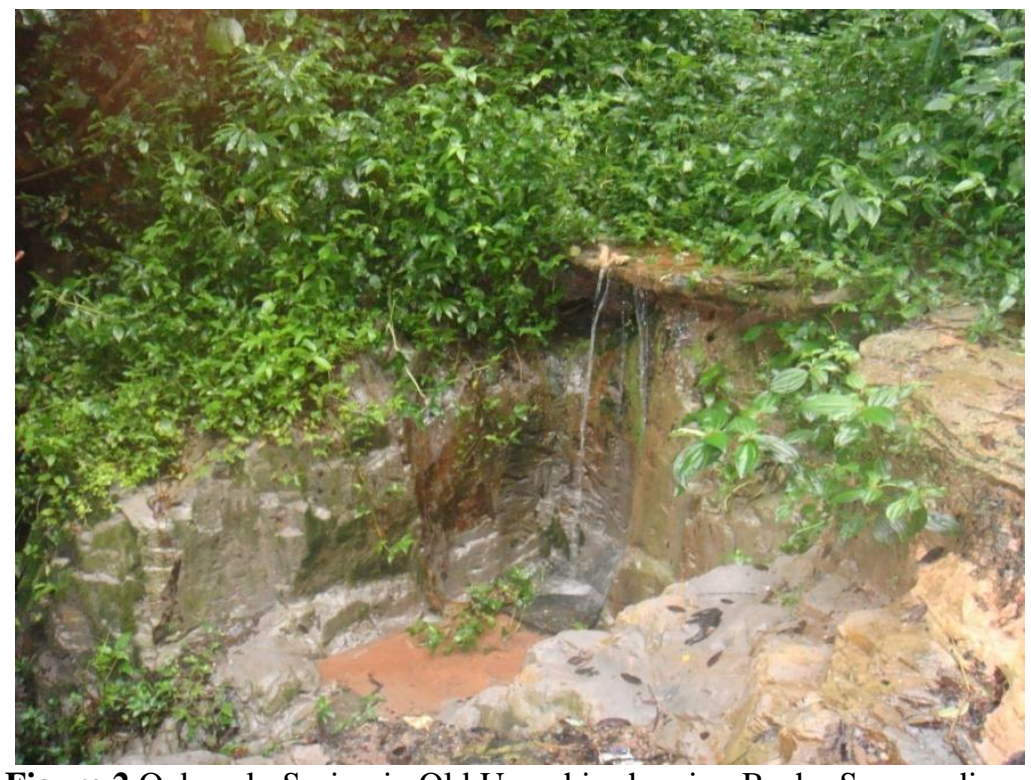

Figure 2.Ogbanelu Spring in Old Umuahia showing Bushy Surroundings

\section{(c) Streams (Oyivo, IyiUmuovo and IyiOkwu)}

These surface water bodies have been a major source of water in Old Umuahia over time.

Presently, they are unable to adequately support the community due to silting up of the streams, shrubs overgrowth and erosion of the access. The quality of the water is also questionable.

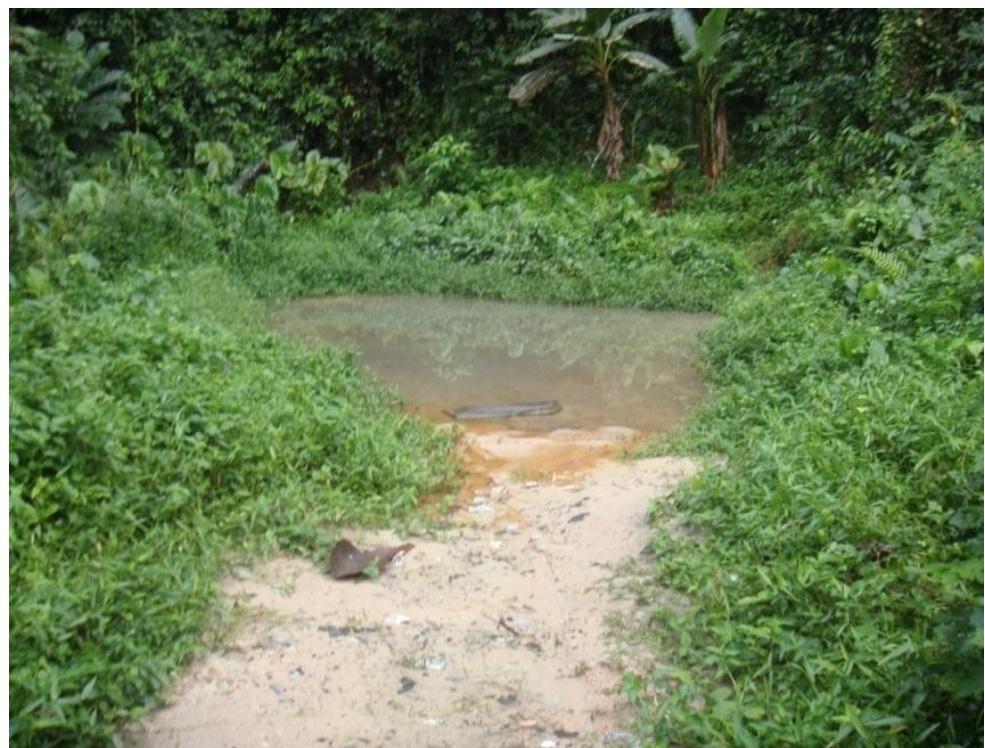

Figure 3 Oyivo Stream in Old Umuahia showing shallow nature and bushy surroundings 


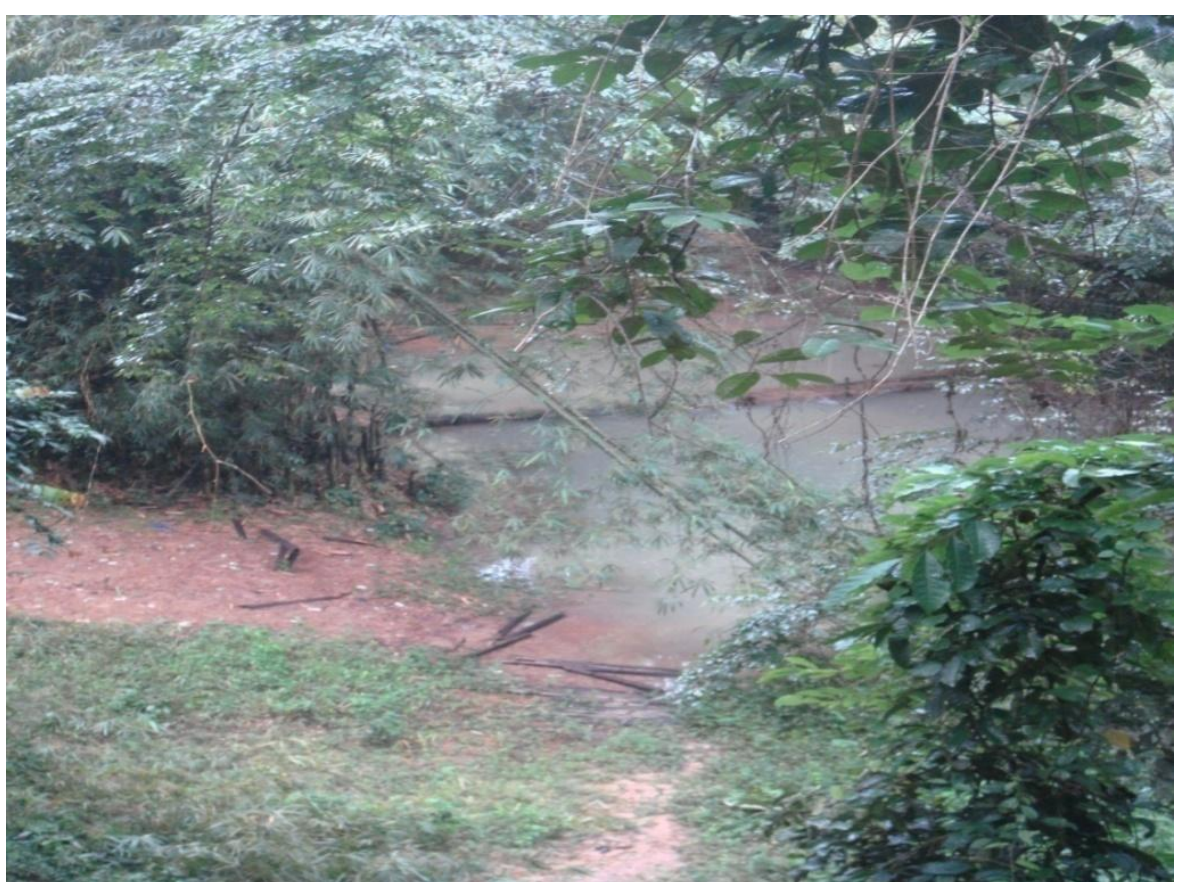

Fig 4.IyiOkwu Stream in Old Umuahia showing shallow nature and bushy surroundings

\section{(d) Rain Water Harvesting:}

This is seasonal as there are limited rains during the dry season. The quality of water collected also depends on the type of roofing sheets used in buildings and the collection/storage.

\section{(e) Private Water Boreholes:}

This is the most popular source of water for domestic and industrial purposes in Old Umuahia. Private individuals sink boreholes in their compounds to provide water for their needs and also sell some to their neighbours.

\section{Data Collection}

\section{Materials and Methods}

The data for this study were obtained from areview of previous relevant works and. field sampling and laboratory analysis of water samples from the various water supply sources.

\section{a. Water Sampling}

Water samples were collected from the identified sources of water in Old Umuahia. The samples were collected in 2-litres plastic sampling containers and transported in ice chests/coolers to the laboratory for quality analysis. Sampling was done using 'thief can' into 2-litres plastic sampling containers. The samples were properly labeled. Insitumeasuremnets were made of $\mathrm{pH}$, Dissolve Oxygen (DO), Temperature, Conductivity, salinity using appropriate meters and the samples were taken to the laboratory for physico-chemical analysis using standard methods.

\section{Results And Discussions}

The coordinates and locations of the sampled souces of water supply are shown in table 1. Results of the analysis for physicochemical parameters (average values) are shown on table 2.

Table 1. GPS Coordinates and Locations of the sampled sources of water supply in the study area

\begin{tabular}{|c|c|}
\hline Location & GPS Coordinates \\
\hline Umueledi Borehole & $5^{\circ} 29^{\prime} 4.2792^{\prime \prime} \mathrm{N} \quad 7^{\circ} 28^{\prime} 13.4497^{\prime \prime E}$ \\
\hline Umuovo Borehole & $5^{\circ} 28^{\prime} 57.6293^{\prime N} 7^{\circ} 28^{\prime} 7.7333^{\prime \prime E}$ \\
\hline Umuechokwu Borehole & $5^{\circ} 28^{\prime} 53.2056^{\prime \prime} \mathrm{N} \quad 7^{\circ} 28^{\prime} 20.0932^{\prime \prime} \mathrm{E}$ \\
\hline Umuobutu Borehole & $5^{\circ} 29^{\prime} 18^{\prime \prime N}$ \\
\hline Oyivo Stream & $7^{\circ} 28^{\prime} 14.9174 " \mathrm{E}$ \\
\hline IyiOkwu Stream & $5^{\circ} 29^{\prime} 9.1378^{\prime \prime} \mathrm{N} \quad 7^{\circ} 28^{\prime} 1.7083^{\prime \prime} \mathrm{E}$ \\
\hline Ogbanelu Spring & $5^{\circ} 29^{\prime} 24.5422^{\prime \prime} \mathrm{N} \quad 7^{\circ} 28^{\prime} 17.0803 " \mathrm{E}$ \\
\hline IyiUmuovo Stream & $5^{\circ} 28^{\prime} 54.2845^{\prime \prime} \mathrm{N} \quad 7^{\circ} 28^{\prime} 5.5898^{\prime \prime} \mathrm{E}$ \\
\hline
\end{tabular}


Quality Implications Of Some Domestic Water Supply Sources In Parts Of Umuahia, Abia State,..

Table 2.Mean values of Physico-chemical parameters of water samples in study area

\begin{tabular}{|c|c|c|c|c|c|c|c|c|c|c|c|}
\hline & $\begin{array}{l}\text { UMU- } \\
\text { ELEDI } \\
\text { BH }\end{array}$ & $\begin{array}{l}\text { UMU } \\
\text { OVO } \\
\text { BH }\end{array}$ & $\begin{array}{l}\text { UMUEC } \\
- \\
\text { HOKW } \\
\text { U BH }\end{array}$ & $\begin{array}{l}\text { UMUO } \\
- \\
\text { BUTU } \\
\text { BH }\end{array}$ & $\begin{array}{l}\text { OYIV } \\
\text { O } \\
\text { STREA } \\
\text { M }\end{array}$ & $\begin{array}{l}\text { IYI } \\
\text { OKWU } \\
\text { STREA } \\
\text { M }\end{array}$ & $\begin{array}{l}\text { OGBA- } \\
\text { NELU } \\
\text { SPRIN } \\
\text { G }\end{array}$ & $\begin{array}{l}\text { IYI } \\
\text { UMUOV } \\
\text { O } \\
\text { STREAM }\end{array}$ & $\begin{array}{l}\text { TAN- } \\
\text { KER }\end{array}$ & $\begin{array}{l}\text { WHO } \\
\text { STAN- } \\
\text { DARD }\end{array}$ & $\begin{array}{l}\text { REM- } \\
\text { ARK }\end{array}$ \\
\hline pH & 4.98 & 5.0 & 4.9 & 4.95 & 4.9 & 5.0 & 5.15 & 5.1 & 5.14 & $6.5-7.5$ & Aci-dic \\
\hline Turbi-dity & 0.65 & 0.126 & 0.37 & 0.135 & 0.233 & 0.3 & 0.39 & 0.47 & 0.88 & 5 NTU & ok \\
\hline $\begin{array}{l}\text { Tempe- } \\
\text { rature }\end{array}$ & 25.68 & 25.83 & 25.72 & 26.58 & 25.0 & 25.5 & 26.96 & 24 & 29.88 & - & ok \\
\hline Hard-ness & 3.74 & 3.92 & 3.61 & 4.026 & 5.78 & 6.11 & 5.28 & 5.86 & 3.76 & $200 \mathrm{mg} / \mathrm{l}$ & ok \\
\hline $\begin{array}{l}\text { Conduc- } \\
\text { tivity }\end{array}$ & 50.83 & 51.9 & 56.7 & 52.5 & 34.1 & 35.5 & 36.2 & 35.9 & 17.7 & - & ok \\
\hline TDS & 33.24 & 33.95 & 36.9 & 33.5 & 23.08 & 23 & 23.4 & 23.088 & 11.5 & $500 \mathrm{mg} / \mathrm{l}$ & ok \\
\hline Salinity & 24.35 & 25.06 & 23.3 & 22 & 14.4 & 13.2 & 16.28 & 14.4 & 8.61 & $250 \mathrm{mg} / \mathrm{l}$ & ok \\
\hline DO & 14.33 & 14.08 & 11.33 & 10.1 & 6.717 & 6.21 & 8.71 & 6.71 & 7 & - & ok \\
\hline Iron & 0.08 & 0.086 & 0.086 & 0.06 & 0.1 & 0.098 & 0.09 & 0.098 & 0.115 & $0.3 \mathrm{mg} / \mathrm{l}$ & ok \\
\hline Manganese & 0.031 & 0.05 & 0.04 & 0.036 & 0.048 & 0.043 & 0.03 & 0.046 & 0.06 & $\begin{array}{l}0.05 \\
\mathrm{mg} / \mathrm{l}\end{array}$ & ok \\
\hline Chromium & 0.035 & 0.018 & 0.019 & 0.021 & 0.022 & 0.017 & 0.017 & 0.018 & 0.014 & $\begin{array}{l}0.05 \\
\mathrm{mg} / \mathrm{l}\end{array}$ & ok \\
\hline Sulphate & 0.21 & 2.26 & 2.05 & 2.28 & 2 & 1.1 & 2.18 & 1.61 & 2.58 & $\begin{array}{c}0 \\
\mathrm{mg} / \mathrm{l}\end{array}$ & ok \\
\hline Copper & 0.03 & 0.0316 & 0.033 & 0.028 & 0.0316 & 0.031 & 0.04 & 0.03 & 0.0316 & 0.05 & ok \\
\hline Colour & 5 & 5 & 5 & 5 & 5 & 5 & 5 & 5 & 5 & 15 NTU & ok \\
\hline Chloride & 10.02 & 10.02 & 10.85 & 10.13 & 8.89 & 9.53 & 9.53 & 9.418 & 8.106 & $250 \mathrm{mg} / \mathrm{l}$ & ok \\
\hline $\begin{array}{l}\text { Total } \\
\text { Alkal-inity }\end{array}$ & 0.053 & 0.052 & 0.05 & 0.049 & 0.051 & 0.0517 & 0.051 & 0.05 & 0.051 & - & ok \\
\hline Zinc & 0.88 & 0.98 & 0.88 & 0.866 & 1.08 & 1 & 0.86 & 1 & 0.766 & $5 \mathrm{mg} / \mathrm{l}$ & ok \\
\hline Nitrate & BDL & BDL & BDL & BDL & BDL & BDL & BDL & BDL & BDL & $10 \mathrm{mg} / \mathrm{l}$ & ok \\
\hline $\begin{array}{l}\text { Total } \\
\text { coliform }\end{array}$ & 8 & $\mathbf{0}$ & 0 & 8 & 1 & $\mathbf{0}$ & 0 & 1 & 4 & 0 & Not ok \\
\hline $\begin{array}{l}\text { Taste/ } \\
\text { Odour }\end{array}$ & $\begin{array}{l}\text { Unobje } \\
\text { ct- } \\
\text { ionable }\end{array}$ & $\begin{array}{l}\text { Unobj } \\
\text { ect- } \\
\text { ionabl } \\
\text { e }\end{array}$ & $\begin{array}{l}\text { Unobject } \\
\text {-ionable }\end{array}$ & $\begin{array}{l}\text { Unobje } \\
\text { ct- } \\
\text { ionable }\end{array}$ & $\begin{array}{l}\text { Unobje } \\
\text { ctionab } \\
\text { le }\end{array}$ & $\begin{array}{l}\text { Unobje- } \\
\text { ctionabl } \\
\text { e }\end{array}$ & $\begin{array}{l}\text { Unobjet } \\
\text {-ionable }\end{array}$ & $\begin{array}{l}\text { Unobjecti } \\
\text { onable }\end{array}$ & $\begin{array}{l}\text { Unobj } \\
\text { et- } \\
\text { ionabl } \\
\text { e }\end{array}$ & $\begin{array}{l}\text { Unobjec } \\
\text { tionable }\end{array}$ & ok \\
\hline
\end{tabular}

The $\mathrm{pH}$ values for the water from the study area is acidic. $\mathrm{pH}$ ranges from $4.9-5.15$ with a mean of 5.02 (figure 5).World Health Organisation recommends that public water systems maintain $\mathrm{pH}$ levels of between 6.5 and 8.5.Low $\mathrm{pH}$ in water causes bitter metallic taste and leads to corrosion. Acidic water is aggressive even to some organs in the body. Figures $5-17$ are graphical representation of the results of the physico-chemical analysis.

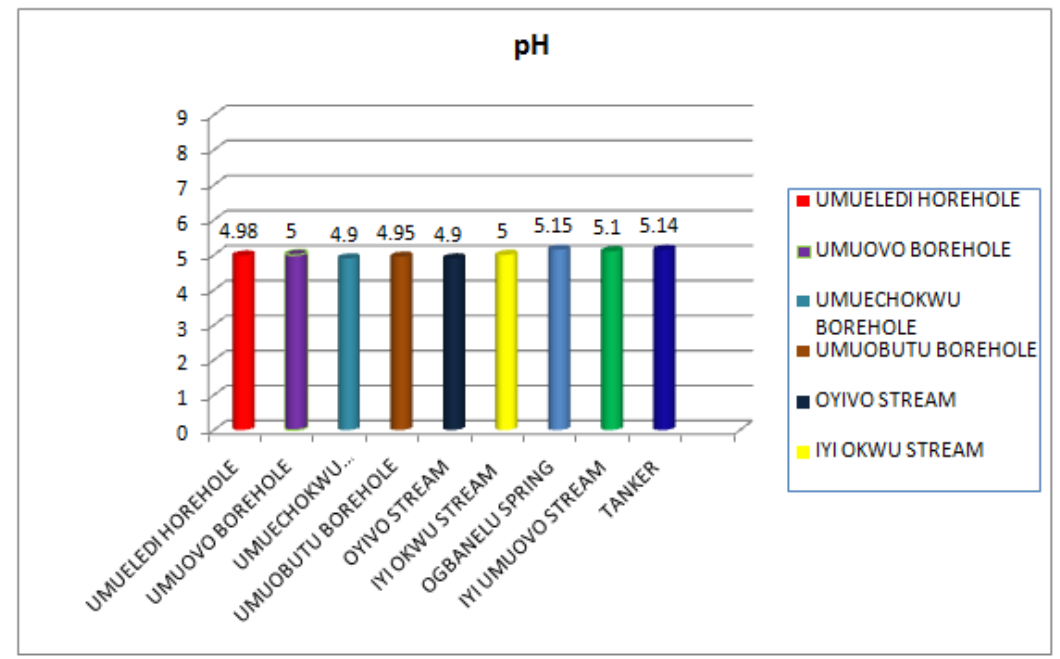

Fig 5. $\mathrm{pH}$ values of water from different sources of water supply in study area

The turbidity values for the water sources under study were well under the WHO/EPA limit of 5 NTU. Turbidity in drinking water is caused by the presence of inorganic particulate matter in groundwater.Hardness caused by calcium and magnesium is usually indicated by precipitation of soap scum and the need for excess 
use of soap in washing. Depending on the interaction of other factors, such as $\mathrm{pH}$ and alkalinity, water with hardness above approximately $200 \mathrm{mg} /$ litre may cause scale deposition in the treatment works, distribution system and pipe work and tanks within buildings. The hardness content of the water sources under review were well below the 200mg/l threshold (WHO, 1984) (figure 6).

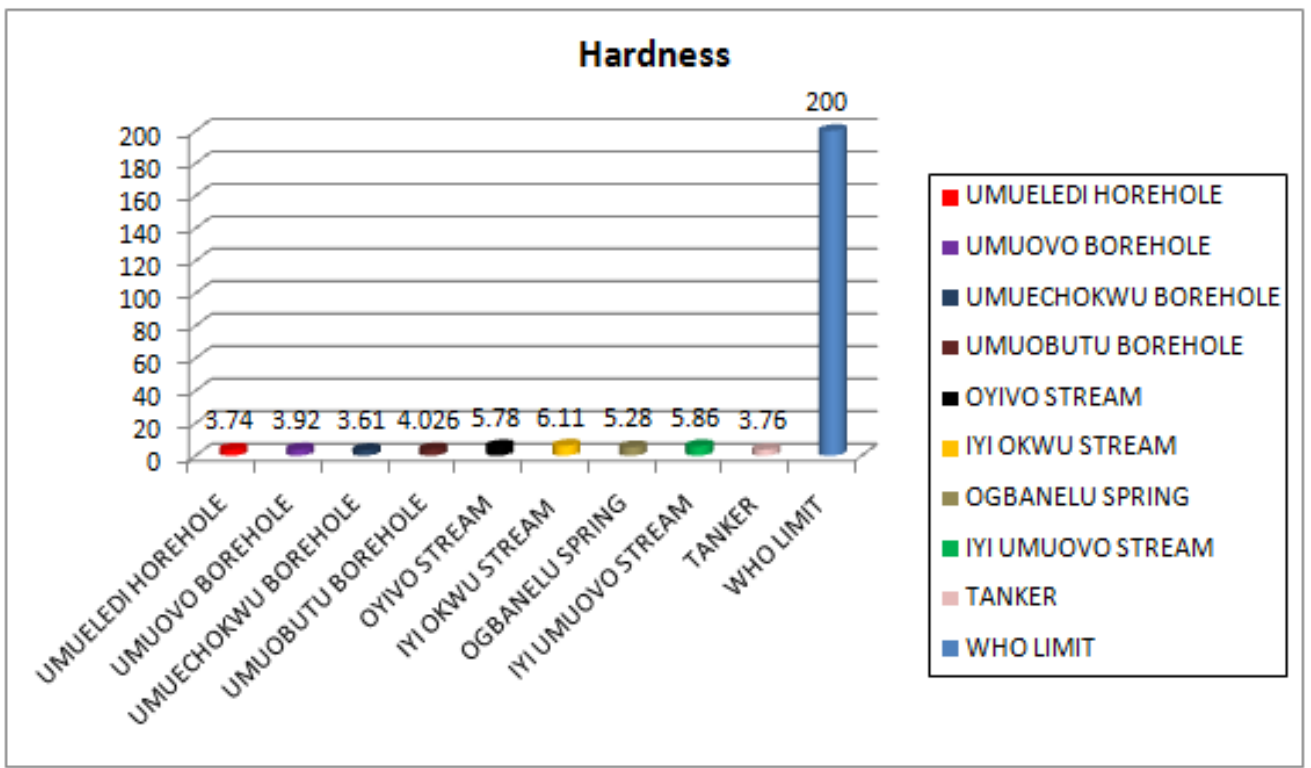

Fig 6.Total Hardness values for water from different sources of study area

The Dissolved Oxygen content of the sources under study ranged from 6.21 - 14.33, (figure7). The dissolved oxygen content of water is influenced by the source, and temperature of the water Depletion of dissolved oxygen in water supplies can encourage the microbial reduction of nitrate to nitrite and sulfate to sulfide. It can also cause an increase in the concentration of ferrous iron in solution.

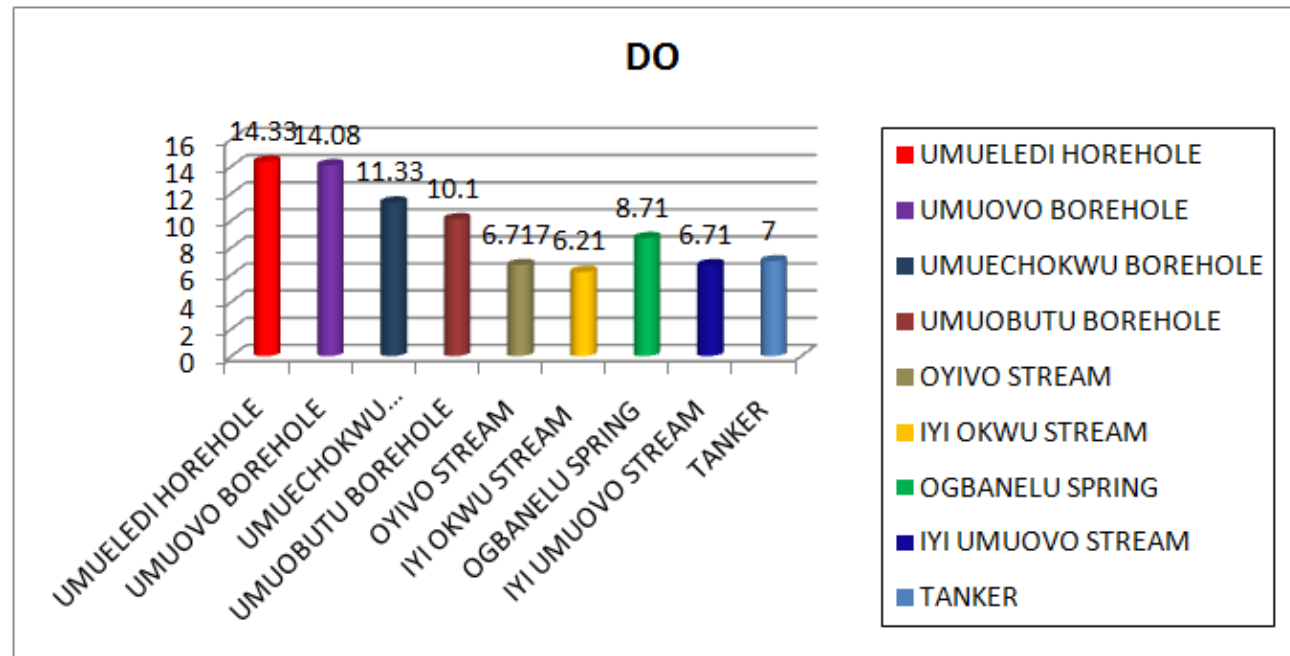

Fig 7. Dissolved Oxygen values of water from different sources in the study area

The WHO set a limit of $0.3 \mathrm{mg} / \mathrm{l}$ as highest concentration of iron in drinking water supplies. The Nigerian Standard Organisation set a limit of 0.1 as highest desirable while FEPA has a limit of $0.5 \mathrm{mg} / \mathrm{l}$. Iron concentration in all the sources of water studied fall below NSO limit apart from the water from Tanker which was marginally above the limit of $0.1 \mathrm{mg} / 1$ (figure 8). Anaerobic groundwater may contain ferrous iron at concentrations of up to several milligrams per litre without discoloration or turbidity in the water when directly pumped from a well. On exposure to the atmosphere, however, the ferrous iron oxidizes to ferric iron, giving an objectionable reddish-brown colour to the water.Iron also promotes the growth of "iron bacteria," which derive their energy from the oxidation of ferrous iron to ferric iron and in the process produce slimy filamentous, slimy coating on the surface of water that can clog piping network. At levels above $0.3 \mathrm{mg} / \mathrm{l}$, iron stains laundry and 
plumbing fixtures. There is usually no noticeable taste at iron concentrations below $0.3 \mathrm{mg} / \mathrm{l}$, althoughturbidity and colour may develop.

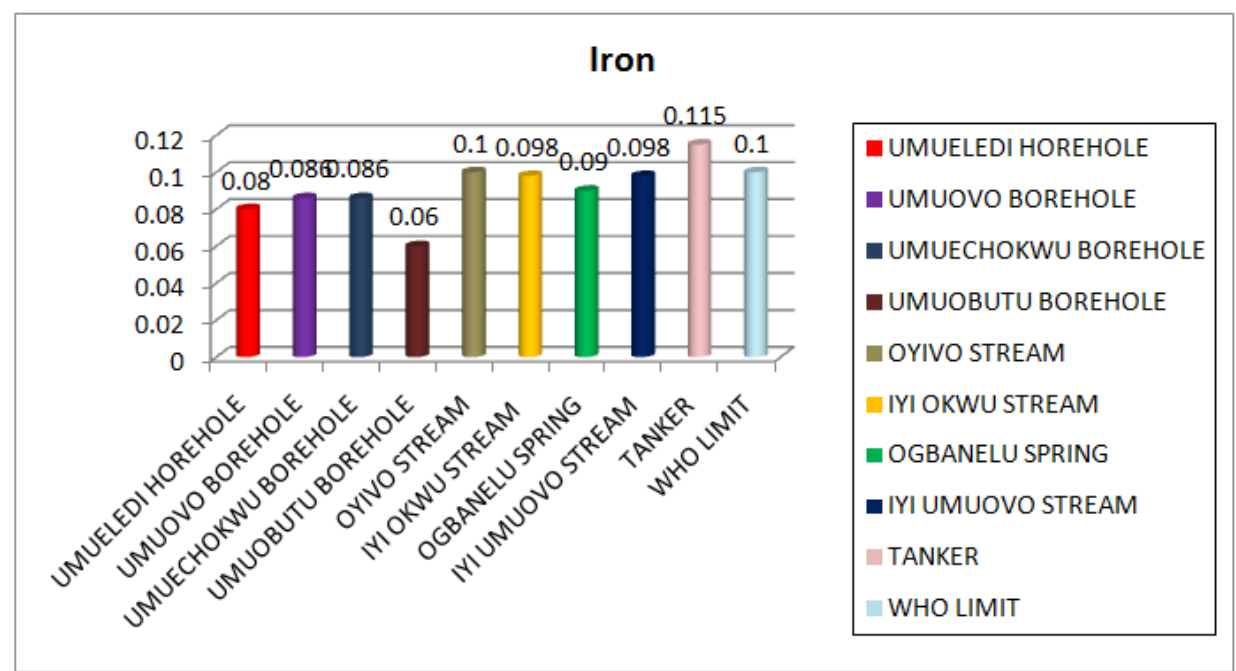

Fig 8. Iron content in water from different sources in the study area

At levels exceeding $0.1 \mathrm{mg} / \mathrm{l}$, manganese in water supplies causes an undesirable taste in water/beverages and stains sanitary wares and laundry. The presence of manganese in drinking-water, like that of iron, may lead to the accumulation of deposits in the distribution system. Concentrations below $0.1 \mathrm{mg} / \mathrm{litre}$ are usually acceptable to consumers. Even at a concentration of $0.2 \mathrm{mg} / \mathrm{l}$, manganese will often form a coating on pipes, which may slough off as a black precipitate. The WHO/and NSO guideline value for manganese is 0.05 as highest desirable and $0.5 \mathrm{mg} / \mathrm{l}$ as maximum permissible. From figure 9 , the water samples from sources under study conformed to the most stringent of these limits which is $0.05 \mathrm{mg} / \mathrm{l}$.

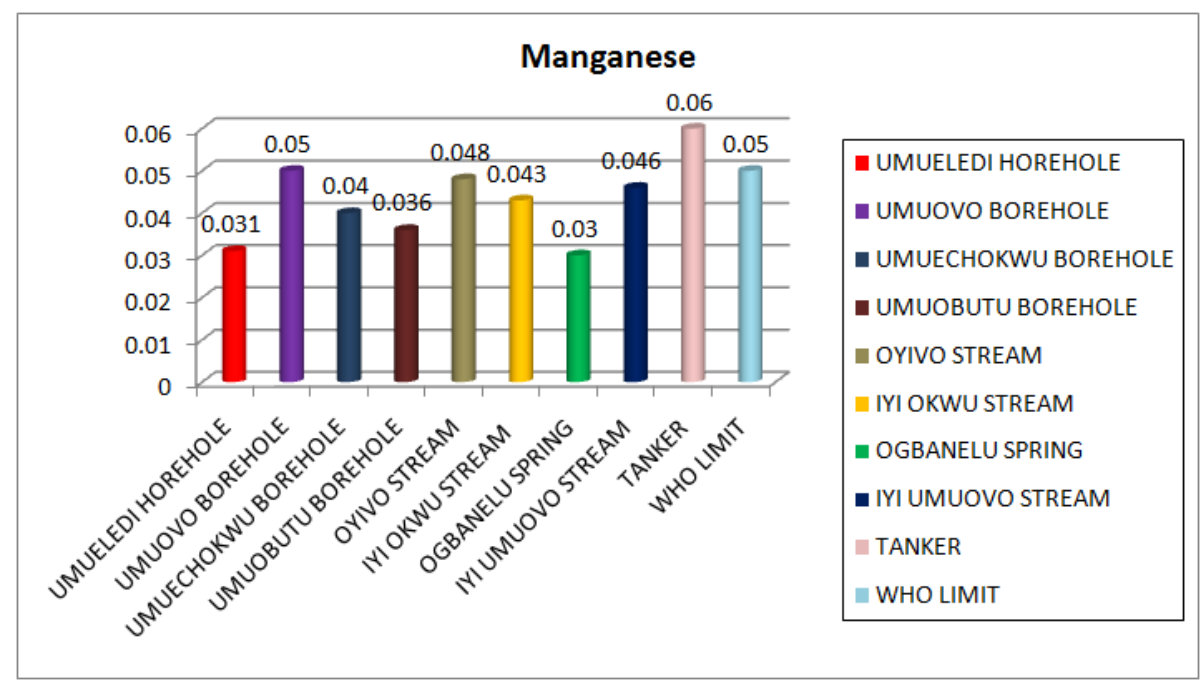

Fig 9.Manganese content in water from various sources in the study area

The concentration of the heavy metals, chromium, copper and zinc in water from the various sources were also investigated. WHO limit for total chromium in drinking water is $0.05 \mathrm{mg} / \mathrm{l}$ while the FEPA limit for chromium is $0.1 \mathrm{mg} / \mathrm{l}$. Chromium can potentially cause serious health problems when people are exposed to it at levels above the maximum concentration level (mcl) for relatively short periods of time. Chromium (VI) oxide is a strong oxidant. Upon dissolution chromium acid is formed, which corrodes the organs. It may cause cramps and paralysis. The lethal dose is approximately $1-2 \mathrm{~g}$. Most countries apply a legal limit of $50 \mathrm{ppb}$ chromium in drinking water. The chromium levels of water in the study area were within these limits.

Copper in drinking-water may increase the corrosion of galvanized iron and steel fittings. Staining of laundry and sanitary wares occurs at copper concentrations above $1 \mathrm{mg} / \mathrm{litre}$. At levels above $5 \mathrm{mg} / \mathrm{l}$, copper also imparts a colour and an undesirable bitter taste to water. The NSO has the highest desirable limit of $0.05 \mathrm{mg} / \mathrm{l}$ 
and a maximum permissible limit of $0.5 \mathrm{mg} / \mathrm{l}$ for copper while the WHO and FEPA has $1.5 \mathrm{mg} / \mathrm{l}$ as the maximum permissible limit. Concentration of copper in the water samples from all the sources under investigation are shown in figure 10.

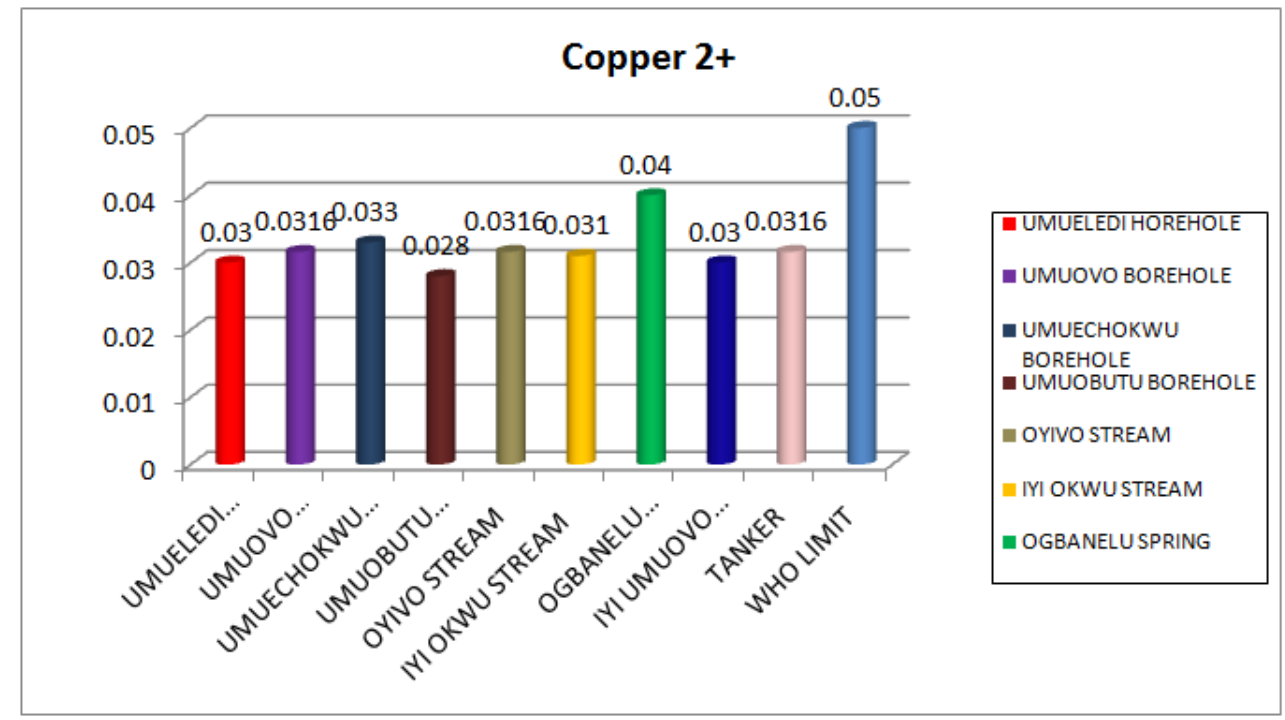

Fig 10. Copper content in water from various sources in the study area

Zinc imparts an undesirable taste to water at a taste threshold concentration of about $4 \mathrm{mg} / \mathrm{l}$ (as zinc sulfate). Water containing zinc at concentrations in excess of 3-5 mg/l may appear opalescent and develop a greasy film on boiling. WHO/FEPA limit is $5 \mathrm{mg} / \mathrm{l}$ (highest desirable and $15 \mathrm{mg} / \mathrm{l}$ (maximum permissible). Concentration of zinc in water samples from the study sources all fall within this limit.

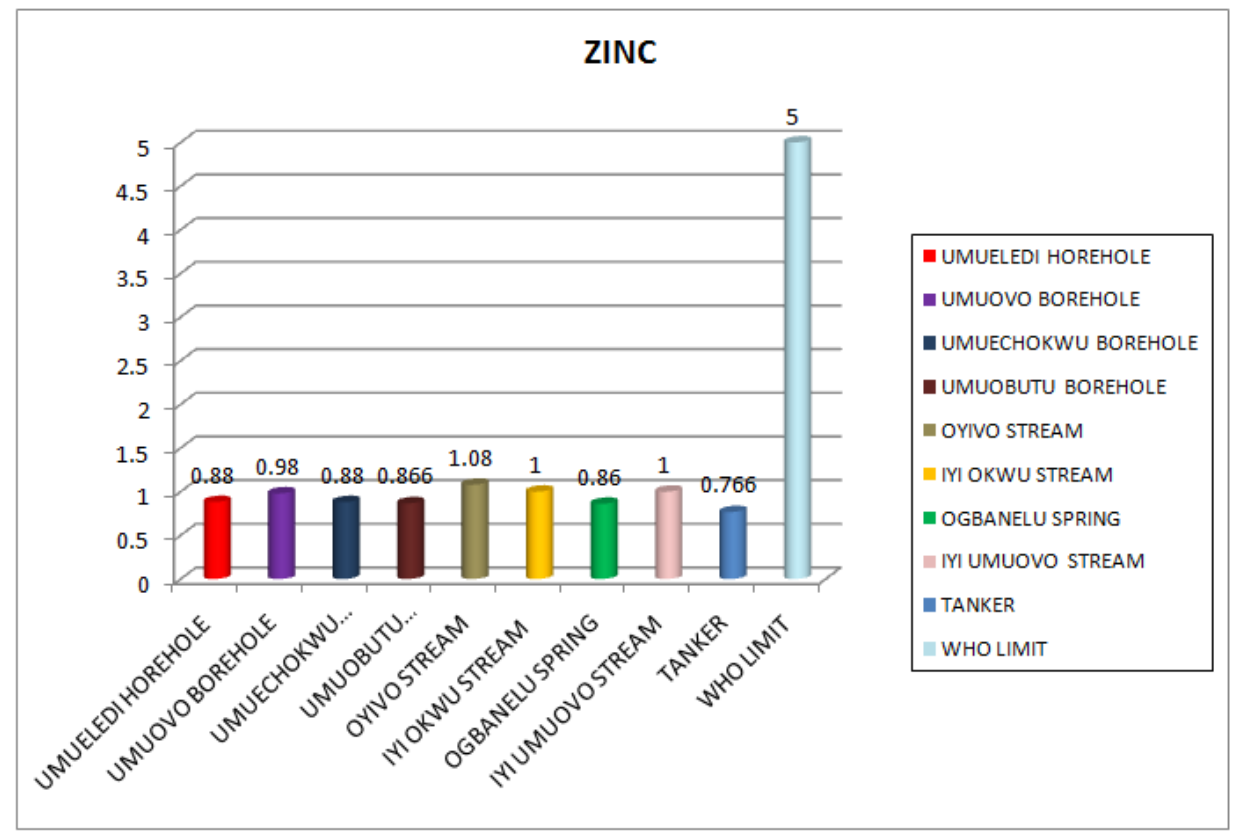

Fig 11.Zinc concentration in various water sources in the study area

The presence of sulphate in drinking-water can cause noticeable salty taste and very high levels might cause a laxative effect in unaccustomed consumers. Taste impairment varies with the nature of the associated cation; taste thresholds have been found to range from $250 \mathrm{mg} / \mathrm{l}$ for sodium sulfate to $1000 \mathrm{mg} / \mathrm{l}$ for calcium sulfate. It is generally considered that taste impairment is minimal at levels below $200 \mathrm{mg} / \mathrm{l}$. WHO/FEPA/NSO have a limit of $200 \mathrm{mg} / \mathrm{l}$ (highest desirable) and $400 \mathrm{mg} / \mathrm{l}$ (maximum permissible) for suphate in drinking water supplies. All the samples from the sources under study conformed to the recommendations. 
High concentrations of chloride and salinity in general give a salty taste to water and beverages.

Concentrations in excess of $250 \mathrm{mg} /$ litre are increasingly likely to be detected by taste, but some consumers may become accustomed to low levels of chloride-induced taste. WHO limit for chloride in drinking water is $250 \mathrm{mg} / \mathrm{l}$. Figures 12 and 13 show the respective values of salinity and chloride in the various water sources. The values fall within the acceptability threshold.

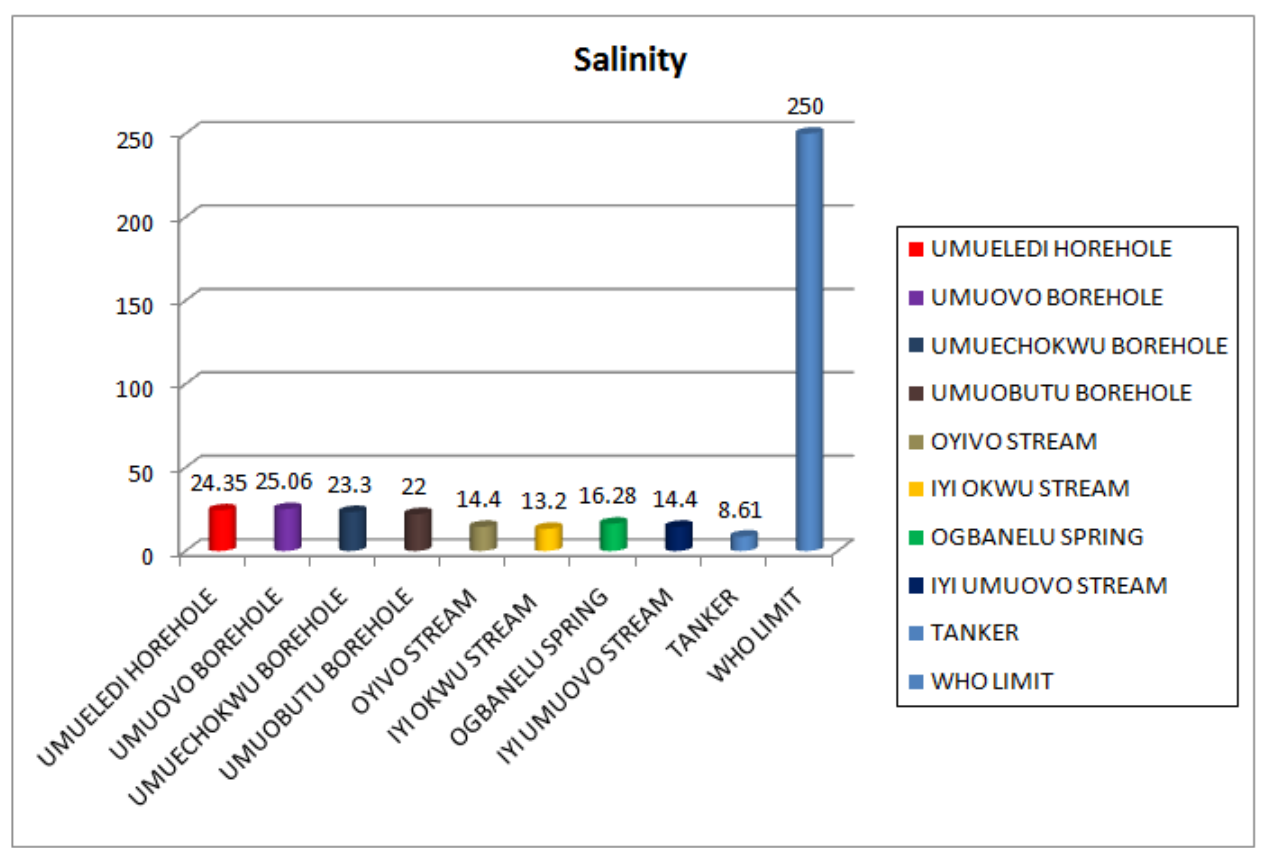

Fig 12. Salinity values in water samples from various sources in the study area

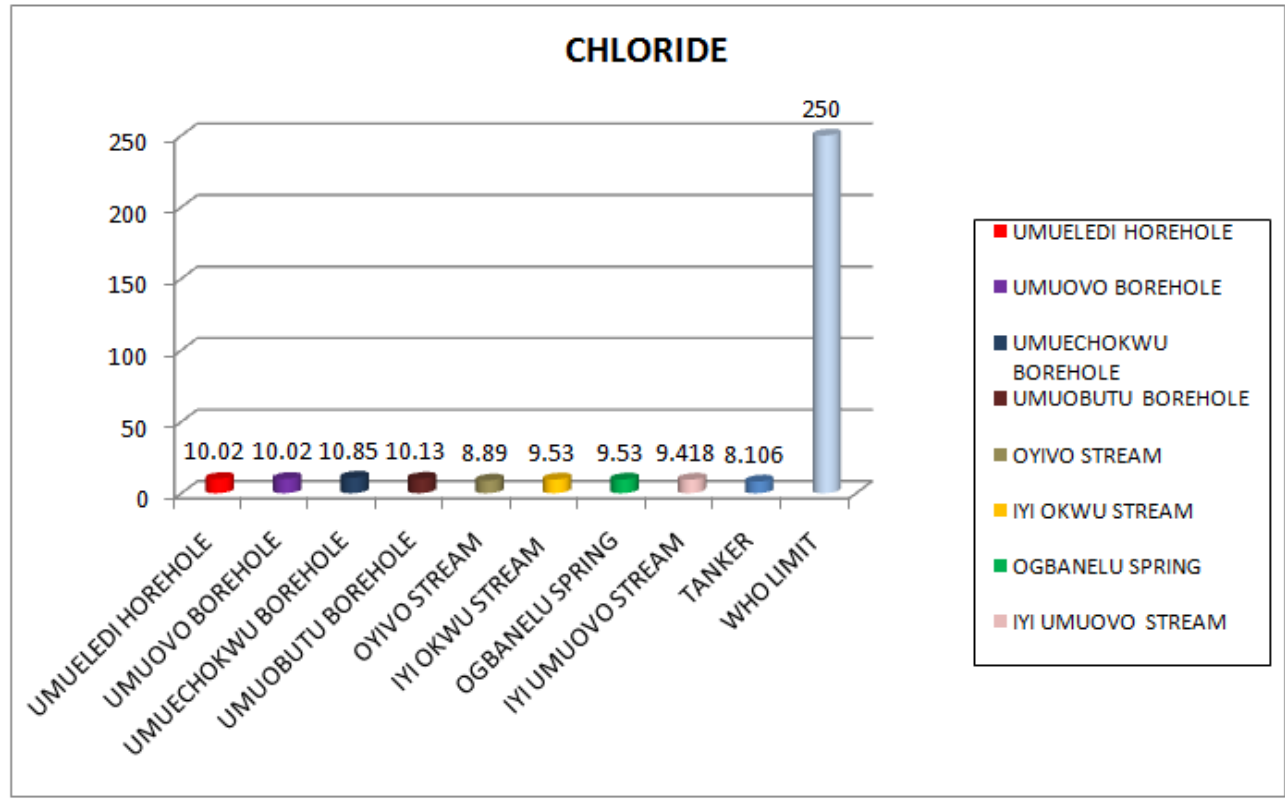

Fig 13. Values of Chloride in various water in the study area

Total alkalinity is a measure of the buffering capacity of water or its ability to resist sudden changes in pH.Measuring alkalinity is important in determining the ability of a water source to neutralize acidic pollution from rainfall or wastewater. It is one of the best measures of the sensitivity of the source to acid inputs. Strongly alkaline waters have an objectionable "soda" taste. FEPA limits alkalinity only in terms of total dissolved solids $(500 \mathrm{ppm})$ and to some extent by the limitation on $\mathrm{pH}$.Highly mineralized alkaline waters also cause excessive drying of the skin due to the fact that they tend to remove normal skin oils. Figure 15 shows the alkalinity values of water from the various sources. 


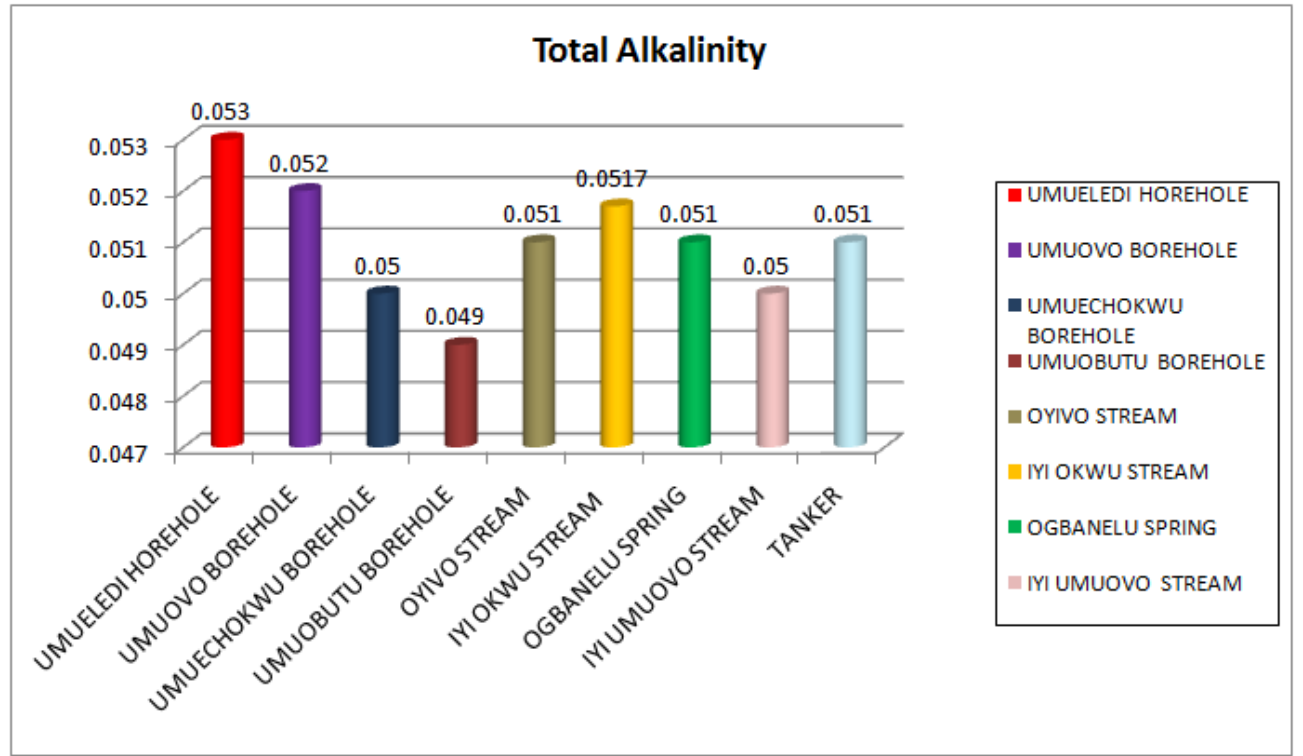

Fig 14. Total Alkalinity in different water sources in the study area

The samples were subjected to microbiological tests. Coliforms are bacteria that are always present in the digestive tracts of animals, including humans, and are found in their wastes. Part of total coliforms can come from sources other than faecal matter. Most coliform bacteria do not cause disease. However, some rare strains of E. coli, can cause serious illness. The presence of coliform bacteria in drinking water increases the risk of contracting a water-borne disease. The ideal drinking water should have zero coliforms count. Only the IyiOkwu stream, OgbaneluSpring, Umuovo and Umuechokwuborehole (figure 16) conformed with this limit. While there was no evidence of the water sources being in contact with faecal matter, it was noticed that the storage facilities at the head stations were left uncovered thereby allowing bird and small animal droppings into the water.

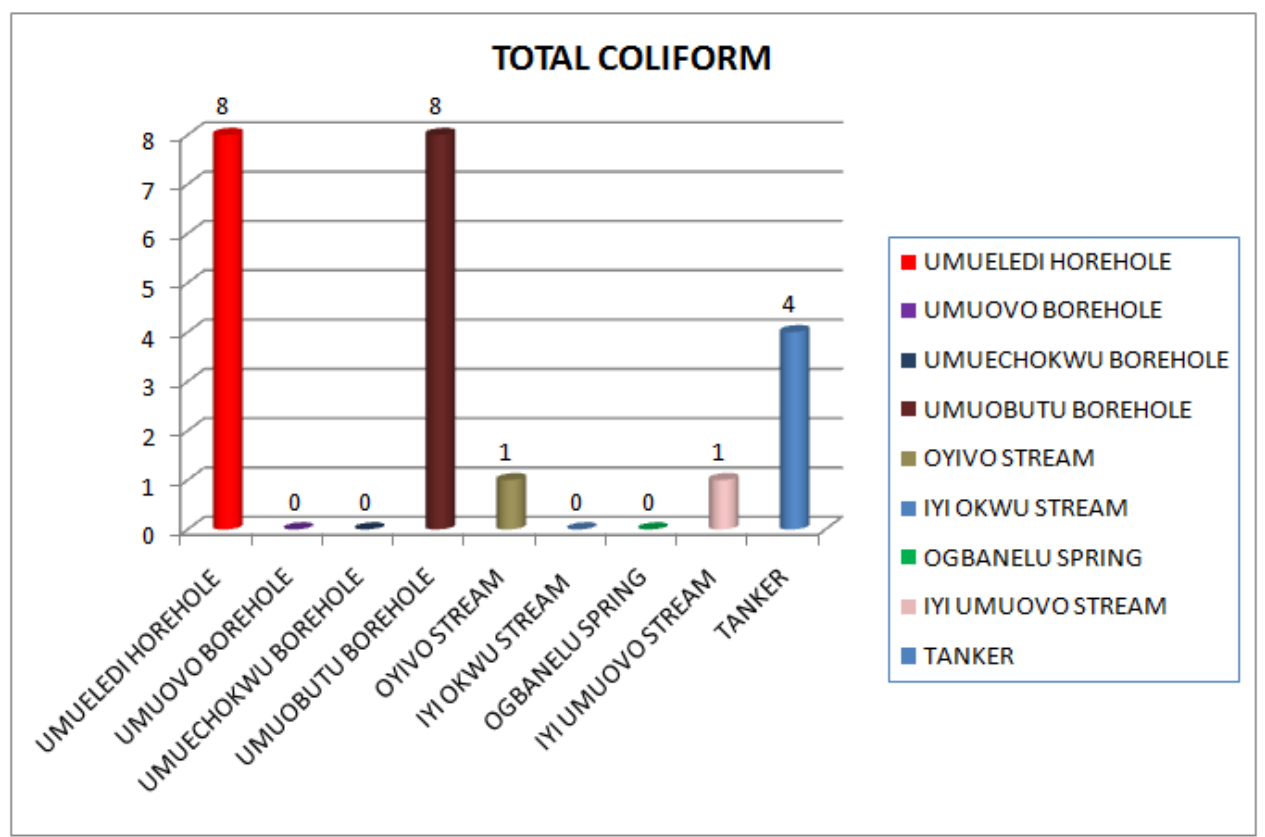

Fig 15.Total Coliform counts in various water sources in the study area

Drinking water should ideally have no visible colour. Colour in drinking-water is usually due to the presence of coloured organic matter (primarily humic and fulvic acids) associated with the humus fraction of soil. Colour is also strongly influenced by the presence of iron and other metals, either as natural impurities or as corrosion products. It may also result from the contamination of the water source with industrial effluents and may be the first indication of a hazardous situation. Levels of colour below 15 TUC are usually acceptable to 
consumers, but acceptability may vary. High colour could also indicate a high propensity to produce byproducts from disinfection processes. All the water sources being investigated conformed to the 15 TUC acceptability threshold (figure 16)

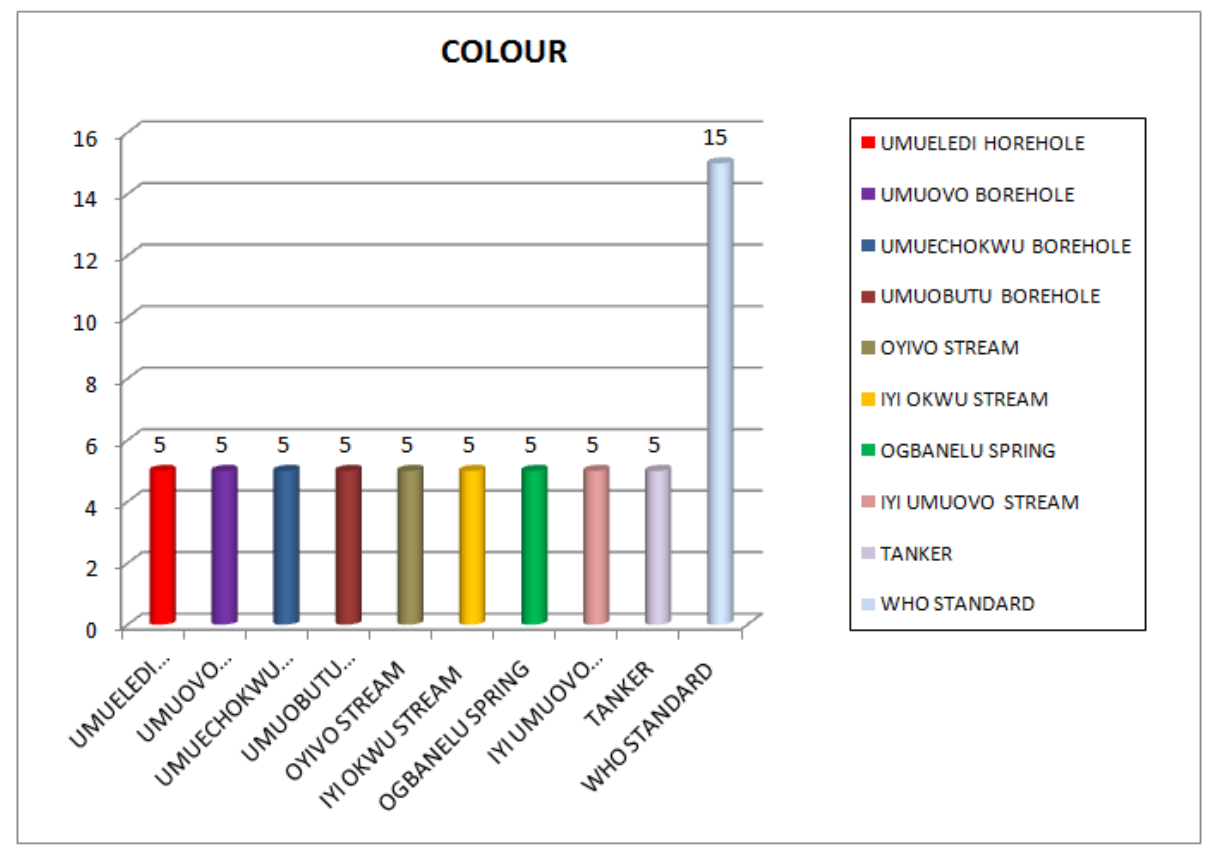

Fig 16. Colour values in water in the study area.

The major sources of nitrates in drinking water are runoff from fertilizer use; leaking from septic tanks, sewage; and erosion of natural deposits. Infants below the age of six months who drink water containing nitrate in excess of the maximum contaminant level $(\mathrm{mcl})$ of $10 \mathrm{mg} / \mathrm{l}$ could become seriously ill, and if untreated, may die. Symptoms include shortness of breath and blue baby syndrome. The nitrate levels of all the water sources studied were below detectable limits (table 2). The environment Ministers Guidelines for Canadian drinking water Quality (1996) has a limit of 500mg/l for TDS in drinking water. The TDS values of the water sources being studied are compliant to this limit.The presence of high levels of TDS is objectionable to consumers, owing to excessive scaling in water pipes, heaters, boilers and household appliances.

Temperature in the water sources varies from $24^{\circ} \mathrm{C}$ at IyiUmuovostrean to $29.88^{\circ} \mathrm{C}$ in the samples from vending tanker. Samples from borehole exhibit fairly consistent temperature ranging between $25.62^{\circ} \mathrm{C}$ and $26.58^{\circ} \mathrm{C}$ (figure 17). All the values fall within WHO specification.

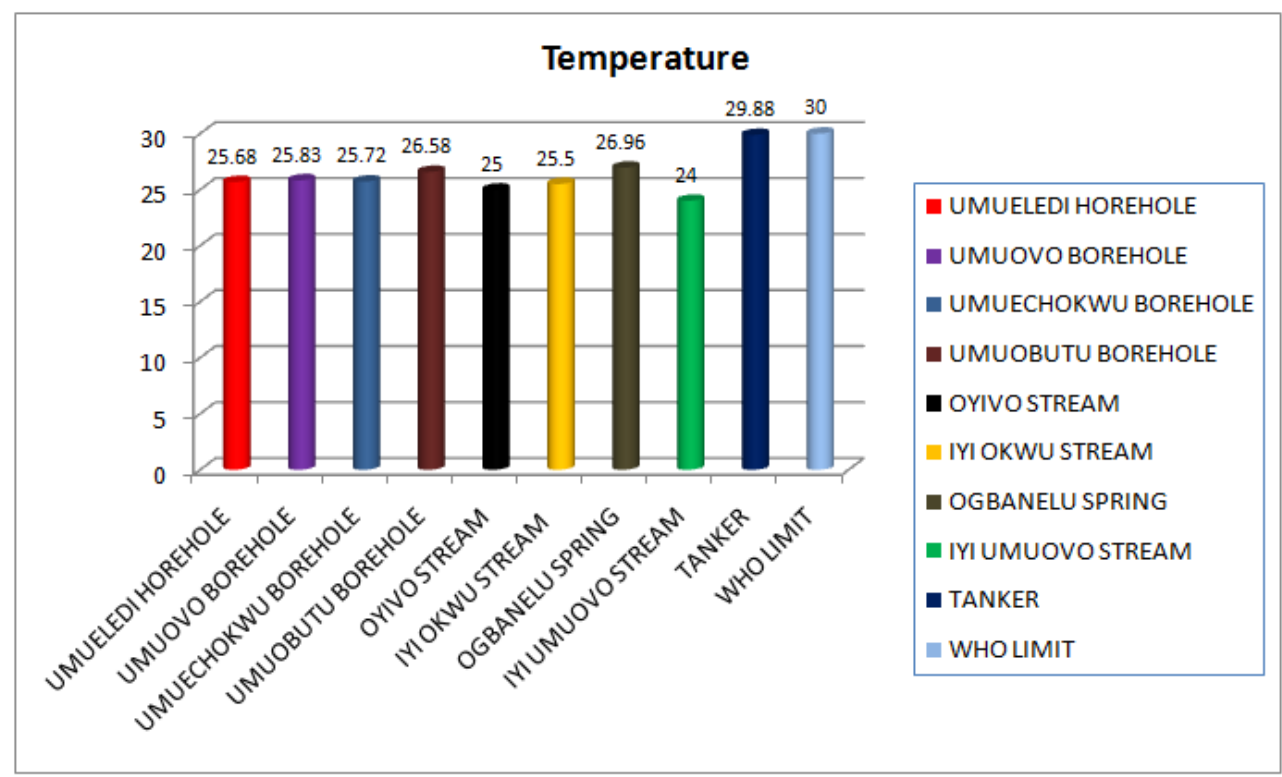

Fig 17. Values of Temperature in different sources of water in the study area 


\section{Conclusion and Recommendations}

The daily water needs of the inhabitants of the study area is from Ogbanelu Spring water, Oyivo, IyiOkwuand IyiUmuovo streams, 4 boreholes located at Umueledi, Umuechokwu, Umuobutu and Umuovo. Water is also obtained from commercial water vendors who deliver their supplies in motorized or manual trucks and also from rainwater harvesting. Access to the spring and stream sources are very bad and eroded.There is evidence of a very prolific aquifer that has the capacity of providing water for Old Umuahia District judging from the groundwater reserve and hydraulic properties of the area.. Available rainfall data also shows that the study area has adequate rainfall to recharge the ground water in order to avoid depletion. The quality of the various sources is generally good except that the water is acidic with mean $\mathrm{pH}$ value of $5.03 \pm 0.086$. The low $\mathrm{pH}$ in the water from boreholes is largely due to aquifers being overlain by lateritic sands and sandstones in various stages of consolidation, Ofodile (1972). Similar observations were made by Du Preeze (1975) about groundwater in Northern Nigeria. Thepresence of coliform bacteria in some sources also pose a major quality issue. The quality of water delivered by water vendors is the worst while ground water quality offers the best choice in terms of quality.It is recommended that more boreholes be drilled in area to adequately provide potable water to cater for their water needs.

\section{References}

[1]. Abii,T.A.,\&Nwabienvanne E.U, (2007). Investigation on Trace Metals Content of some Selected Borehole Water aroundUmuahiaMetroplolis. Research Journal of Applied Sciences, 2(4), 494-497.

[2]. Akpah, F.A, \&Ezeigbo H.I. (2010).Hydrogeochemical Investigation on Groundwater in Itakpe, Central Nigeria.Water Resources, 20(2), $72-80$.

[3]. Aller, L.,Bennett, T., Lehr, J.H., \& Petty, R.J.(1985) DRASTIC: A Standardized System for Evaluating Groundwater Pollution Potential using HydrogeologicSettings. U.S. EPA, Robert S. Kerr Environmental Research Laboratory, Ada, OK, EPA/600/2$85 / 018,163$

[4]. Ayoade J.O.(1975).Water Resources and their Development in Nigeria. Bulletin International Association for Hydrological Sciences, 20(4), 581-591.

[5]. Cairncross S.\&Valdmanis V., (2004). Water Supply, Sanitation, and Hygiene Promotion, Working Paper No. 28 July 2004.

[6]. Chukwu, G.U. (2008). Water Quality Assessment of Boreholes in Umuahia South Local Government Area of Abia State, Nigeria.The Pacific Journal of Science and Technology. 9(2), 592 - 598.

[7]. duPreez, J.W. \& Barber, W. (1965) .The Distribution and Chemical Quality of Groundwater in NorthernNigeria. Geological Survey of Nigeria Bull, 36,38-45,

[8]. Ebilah-Salmon and Partners, (1994). Investigation of the Existing Water Supply Facilities Within the University Complex, Geophysical Report and Recommendations for Reactivation and Future Exploitation for Potable Water Supply. Federal University of Agriculature, Umudike. pp25

[9]. Efe S.I, (2006). Quality of Rainwater Harvesting for Rural Communities of Delta State, Nigeria Journal of the Environment,26(3),175 -181.

[10]. Igboekwe M.U., Okwueze E.E., \& Okereke C.S. (2006). Delineation of natural aquifer zones from goelectric sounding in Kwa Ibo river watershed, south Eastern Nigeria.Journal for Engineering and Applied Science, 1 (4), 410 -421.

[11]. Ijeh, B. I., \&Udoinyang I.E. (2013). Assessment of the Groundwater Quality in Parts of Imo River Basin, Southeastern Nigeria: The Case of Imo Shale and Ameki Formations.Journal of Water Resource and Protection,.5, 715-722.

[12]. Isirimah, N.O. (2000). Soils and Environmental Pollution Management.Nichdano Publishers, Owerri. Nigeria.

[13]. Mbonu, P.D.C., Ebeniro J.O., Ofoegbu C.O. and Ekine A.S, (1991).Geoelectric Sounding for the Determination of Aquifer Characteristics in Parts of Umuahia Area of Nigeria. Geophisics, 56, 284-291.

[14]. Nkwocha E. E. (2008) Water Supply Deficiency and Implications for Rural Development in the Niger-Delta Region of Nigeria. Social Indicators Research, 90(3), 409-418

[15]. Nwankwoala H.O and Udom G.J. (2011). A Preliminary Review of Potential Groundwater Resources of the Niger Delta. Internationl. Journal of Applied Environmental Science, 6(1),57-70.

[16]. Offodile, M.E. (1992). An Approach to Ground Water study and Development in Nigeria.Mecon services Ltd. Jos Nigeria.pp. 224236.

[17]. Todd, D.K. (1984). Ground water Hydrology, $2^{\text {nd }}$ Edition, John Wiley and sons, New York. p 535

[18]. Uchegbu Smart N.,( 2009).Effective Planning and Management as Critical Factors in Urban Water Supply and Management in Umuahia and Aba, Abia State, Nigeria.Physics and Chemistry of the Earth, Parts A/B/C, 34 (1-2), 23-27

[19]. Ukandu1 J. S., Udom G. J., Nwankwoala H. O. (2011). Hydrochemistry of Groundwater in Umuahia South Local Government Area, Abia State, Nigeria.British Journal of Applied $\quad$ Science \& Technology, 1(4),141-151.

[20]. Uma K. O and Egboka B. C. E. (1988). Problems Of Rural Water Supplies In A Developing Economy: Case Studies Of Anambra and Imo States of Nigeria. Water International, 13 (1), 33 - 45. 